๑ Entomologica Fennica. 27 June 1995

\title{
Oribatid species (Acari, Oribatida) new to the fauna of Finland
}

\author{
Ritva Niemi
}

\begin{abstract}
Niemi, R. 1995: Oribatid species (Acari, Oribatida) new to the fauna of Finland. - Entomol. Fennica 5:213-217.

Sixteen species of oribatids new to Finland are recorded, five of which [Microzetorchestes emeryi (Goggi), Oppiella minidentata (Subias), Quadroppia michaeli Mahunka, Xylobates capucinus (Berlese) and Oribella sexdentata Berlese] have not previously been recorded in the Nordic countries. Included is a short survey of their occurrence in that region, and records from Finnish localities according to the uniform grid system $\left(27^{\circ} \mathrm{E}\right)$ with $10 \times 10 \mathrm{~km}$ squares.

Ritva Niemi, Zoological Museum, University of Turku, FIN-20500 Turku, Finland
\end{abstract}

Received 20 January 1994, accepted 10 February 1995

\section{Introduction}

The aim of this paper is to update the previous lists of oribatid mites by Karppinen \& Krivolutsky (1982) and by Niemi (1988). Sixteen species new for Finland have subsequently been reported. Some of these, Gymnodamaeus bicostatus (C.L. Koch), Xenillus latus (Nicolet), Odontocepheus elongatus (Michael), Xylobates capucinus (Berlese), and Chamobates spinosus Sellnick, were listed by Nordberg (1936), but Uusitalo (1992) presented evidence that Nordberg's work on mites is unreliable because it contains many erroneous identifications, and because the original material is lost and the localities not clearly specified. Accordingly, I regard Nordberg's identifications as unreliable and will not use them here.

\section{Material and methods}

The material studied originated from unsorted soil samples of the Zoological Museum, University of Turku. The species have been listed, with a short survey of their occurrence in the Nordic Countries, and with records from Finnish localities given according to the uniform grid system $\left(27^{\circ} \mathrm{E}\right)$ with $10 \times 10 \mathrm{~km}$ squares. The systematic order follows Marsall et al. (1987), except for the family Oppiidae, which is listed according to Subias \& Balogh (1989). The identified material has been deposited in the Zoological Museum, University of Turku.

\section{List of species and localities}

Nothridae

Nothrus invenusta (Michael, 1888)

Material: 666:20 Nauvo, Berghamn, Boskär, in Parmelia sp. on rocks, 30.5.1990, R. Niemi, 1 ex. 667:22 Nauvo, Kirjais S, in Parmelia sp. on rocks, 7.6.1981, R. Niemi, 3 exx. - 669:22 Parainen, Tennäs, Lund, in Xanthoria sp. \& Parmelia sp., 24.7.1981, R. Niemi, 60 exx.

This species has been recorded from Sweden (Sellnick \& Forsslund 1955), Norway (Løken 1966) and Denmark (Gjelstrup 1978). 
Gymnodamaeidae

\section{Gymnodamaeus bicostatus (C.L. Koch, 1835)}

Material: 669:23 Parainen, Sydmo, Ippos, in rocky forest with lichen, 6.9.1966, P.T. Lehtinen, 1 ex. $-696: 52$ Kuopio, Vuorilampi, in litter at base of rock wall, 22.8.1973, O.V. Lindqvist, 3 exx.

Dalenius (1960) found this species in Swedish Lapland, while the first record from Norway was by Strand (1910).

\section{Zetorchestidae}

\section{Microzetorchestes emeryi (Goggi, 1898)}

Material: 669:19 Korppoo, Åvensor, in Sedum on rock, 30.7.1966, P. T. Lehtinen, 4 exx. - 669:19 Korppoo, Åvensor, Kirmo, in nest of Lasius fuliginosus under stone 8.7.1985, P.T. Lehtinen, 1 ex.

This species has not previously been found in the Nordic countries, although, according to Schatz (1983), from Central Europe it has been reported from many countries.

\section{Xenillidae}

\section{Xenillus latus (Nicolet, 1855)}

Material: 665:20 Korppoo, Björkö, in maritime deciduous forest, 26.6.1980, P.T. Lehtinen, 49 exx. - 668:17 Houtskari, Jungfruskär, in sand with grass, 29.5.-23.7.1990, K. Heikka \& P.T. Lehtinen, 1 ex. - 668:23 Parainen, Haradsholm, Byön, in forest with Mnium-Rhodobryum, 1.10.1981, P.T. Lehtinen, 2 exx. - 670:20 Korppoo, Åvensor, Hevoslot, in nests of Camponotus, Lasius \& Formica sanguinea, 12.6.1983, P.T. Lehtinen, 2 exx.

The species has been found in Sweden (Dalenius 1950) and in Denmark (Thamdrup 1932).

\section{Carabodidae}

\section{Odontocepheus elongatus (Michael, 1879)}

Material: 665:20 Nauvo, Fårö, in litter of ElymusFucus, 20.6.1991, V. Rinne, 1 ex. - 667:20 Korppoo, Kalgarholm, Hässlö, under bark of decaying pine, 28.7.1986, P.T. Lehtinen, 9 exx. - 669:20 Korppoo, Kärvois, Koivuluoto, from anthill of Formica sp., 14.8.1982, P.T. Lehtinen, 1 ex. - 670:20 Korppoo, Åvensor, Hevoslot, in nests of Camponotus, Lasius \& Formica sanguinea, 12.6.1983, P.T. Lehtinen, 4 exx.
Nordenskiöld (1901) reported Carabodes sp. cfr. elongatus (Mich.) from Finland. Because of the uncertainty of the previous identifications of this species, I consider it to be newly recorded. The species has been recorded by Dalenius (1950) from Sweden and listed by Mehl (1979) from. Norway; according to Hallas (1978) there are many records from Denmark.

\section{Oppiidae}

\section{Berniniella bicarinata (Paoli, 1908)}

Material: 669:19, Korppoo Åvensor, in Sedum on rock, 30.7.1966, P.T. Lehtinen, 1 ex.

Dalenius (1950) has recorded this species from Sweden, Solhøy (1975) from Norway, and Haarløv (1957) from Denmark.

\section{B. sigma (Strenzke, 1951)}

Material: 665:20, Korppoo Björkö, in maritime decidious forest, 26.6.1980, P.T. Lehtinen, 1 ex.

According to Hallas (1978) the only other Nordic country in which this species has been found is Denmark.

\section{Moritzoppia keilbachi (Moritz, 1969)}

Material: 665:20 Korppoo Björkö, in maritime decidious forest, 26.6.1980, P.T. Lehtinen 14 exx. - 666:20 Nauvo Berghamn Boskär, in decaying aspen, 30.5.1990, P.T. Lehtinen, 8 exx - 668:17 Houtskari Jungfruskär, in Juniperus litter at seashore, 29.5.1990, R. Niemi 13 exx. - 668:23 Parainen Haradsholm Byön, in Mnium, 1.10.1981, P.T. Lehtinen, 23 exx. — 668:23 Parainen Haradsholm Byön, in Mnium-Rhodobryum, 1.10.1981, P.T. Lehtinen, 76 exx. - 670:20 Korppoo Avensor Hevoslot, in nests of Camponotus, Lasius \& Formica sanguinea, 12.6.1983, P.T. Lehtinen, 1 ex. — 671:24 Turku Kurala Kylämäki, Vähä-Kohmo, in wood litter on dirt floor of woodshed, 20.6.1990, R. Niemi \& V. Rinne, 11 exx. 671:24 Lieto Vanhalinna, in moist wood litter on floor of old cottage, 8.3.1992, R. Niemi, 49 exx. - 674:19 Uusikaupunki Varanpää Petes, from anthill of Formica sp., 26.6.1984, P.T. Lehtinen, 3 exx. - 674:26 Pöytyä Himainen, in abandoned anthill, 9.4.1983, P.T. Lehtinen, 11 exx. — 674:26 Pöytyä Himainen, in abandoned anthill of Formica polyctena, 9.4.1983, P.T. Lehtinen, 7 exx. 677:19 Uusikaupunki Pyhämaa Santalahti, in abandoned anthill of Formica, 2.10.1982, R. Niemi, 61 exx. - 677:19 Uusikaupunki Pyhämaa Santalahti, from old Formicaanthill, 2.10.1982, R. Niemi, 54 exx. —678:32 Kylmäkoski, 
in horse dung, 25.8.1985, R. Niemi, 3 exx. - 686:25 Kankaanpää Makkaramäki, from Formica polyctenaanthill, 29.9.1986, R. Niemi, 2 exx. - 691:30 Virrat Peltoperä, in anthill of Formica exsecta in dried mud, 10.8.1985, P.T. Lehtinen, 47 exx. - 709:33 Kälviä, in straw litter on dirt floor of haybarn, 1.7.1988, R. Niemi, $>100$ exx. - 772:49 Utsjoki Kevo Nature Reserve, from burned birch forest, 25.6.1986, S. Koponen, 5 exx. 772:49 Utsjoki Kevo Nature Reserve, from birch forest, 10.7.1973, S. Koponen, 1 ex.

Before the description of this species in 1969, a very similar species, $M$. unicarinata, was recorded many times in Finland (Karppinen 1958a, b, c, 1962, Krogerus 1960, Mahunka 1968). However, after my study of the Finnish oribatid material I have found $M$. unicarinata to be very rare in our country, whereas $M$. keilbachi is quite common and sometimes very abundant. The species has been recorded from Sweden (Hippa et al. 1988), but is absent in the lists from Norway and Denmark.

\section{M.(?) tridentata (Forsslund, 1942)}

Material: 735:60 Kuusamo Juuma, in pile of sawdust, 3.8.1982, P.T. Lehtinen, 1 ex.

Recorded in Nordic countries only from Sweden (Forsslund 1942).

\section{Oppiella minidentata (Subias, 1977)}

Material: 772:49 Utsjoki Kevo Nature Reserve, from burned birch forest, 17.9.1986, S. Koponen, 1 ex.

Subias (1977) has described this species from a mountain range north of Madrid. Pérez-Iñigo (1988) considered it an Iberian endemic species.

\section{Quadroppia michaeli Mahunka, 1977}

Material: 665:20 Korppoo Björkö, in maritime deciduous forest, 26.6.1980, P.T. Lehtinen, 96 exx. - 666:20 Nauvo Berghamn Boskär, in spruce litter, 13.9.1990, R. Niemi, 32 exx. - 668:23 Parainen Haradsholm Byön - N, from stand of Mnium-Rhodobryum, 1.10.1981, P.T. Lehtinen, 25 exx. - 668:17 Houtskari Jungfruskär, from Juniperus litter at seashore, 29.5.1990, R. Niemi, 16 exx. — 668:17 Houtskari Jungfruskär, in hazel litter, 12.9.1990, R. Niemi 1 ex. - 669:19 Korppoo Åvensor, on sloping meadow, 30.7.1966, P.T. Lehtinen, 1 ex. - 669:22 Parainen Tennäs Lund, in Xanthoria \& Parmelia, 24.7.1981, R. Niemi, 1 ex. — 671:17 Brändö, in hazel litter, 26.8.1989,
R. Niemi, 52 exx. - 671:24 Turku Kurala Kylämäki, IsoRasi, in attic of old house, 20.6.-22.8.1990, Niemi R. \& Rinne V., 1 ex. - 674:26 Pöytyä Himainen, in abandoned anthill of Formica polyctena, 9.4.1983, P.T. Lehtinen, 5 exx. - 671:24 Turku Varissuo, from Cladonia, 14.11.1982, R. Niemi, 1 ex.

Quadroppia quadricarinata is the only Quadroppia species previously recorded from the Nordic countries (Lundqvist 1987, Hallas 1978, and Mehl 1979). Because both $Q$. michaeli and quadricarinata are very small species, the differences between them can be recognized with certainty only from mounts. Therefore, I believe that in some cases specimens labelled Q. quadricarinata may in fact be $Q$. michaeli.

\section{Scutoverticidae}

Scutovertex sculptus Michael, 1879

Material: 665:20 Nauvo Fårö, in Elymus \& FucusIitter, 20.6.1991, V. Rinne, 3 exx. - 694:63 Liperi Ylämylly, in Formica rufa anthill, 20.8.1986, P.T. Lehtinen, 2 exx.

This species has been recorded previously from Denmark (Gjelstrup 1978). Most finds have been made in Southern and Central Europe (e.g. PérezIñigo 1988 and Gil \& Subias 1990).

\section{Haplozetidae}

\section{Xylobates capucinus (Berlese, 1908)}

Material: 665:20 Korppoo Björkö, in maritime deciduous forest, 26.6.1980, P.T. Lehtinen, 1 ex. - 666:24 Dragsfjärd, at rim of a spring among Mnium sp, 14.8.1982, R. Niemi, 3 exx. - 669:19 Korppoo Åvensor, in Sedum on rock, 30.7.1966, P.T. Lehtinen, 2 exx. - 669:20 Korppoo Åvensor Kirmo, in nest of Lasius fuliginosus under stone, 8.7.1985, P.T. Lehtinen, 1 ex. - 677:19 Uusikaupunki Pyhämaa Santalahti, in Hippophae rhamnoides-litter, 2.10.1982, R. Niemi, 1 ex.

Not previously found in the Nordic countries. In Southern and Central Europe this species is common (Schatz 1983).

\section{Chamobatidae}

\section{Chamobates spinosus Sellnick, 1928}

Material: 665:20 Korppoo Björkö, in maritime deciduous forest, 26.6.1980, R. Niemi, 19 exx. - 668:17 
Houtskari Jungfruskär, in Juniperus litter at seashore, 29.5.1990, R. Niemi, 12 exx. - 671:17 Brändö, in hazel litter, 26.8.1989, R. Niemi, 2 exx. - 671:24 Lieto Vanhalinna, in moist wood litter on floor of old cottage, 8.3.1992, R. Niemi, 4 exx. - 677:19 Uusikaupunki Pyhämaa Santalahti, in old Formica-nest, 2.10.1982, R. Niemi, 23 exx. - 677:19 Uusikaupunki Pyhämaa Santalahti, in abandoned anthill of Formica sp., 2.10.1982, R. Niemi, 73 exx. - 6903:422 Muurame, in forest of Myrtillus-type (ca. 100 years old), 1991, J. Laakso, 1 ex.

This species has been recorded from Sweden (Dalenius 1960), and from Denmark (Thamdrup 1932).

\section{C. voigtsi (Oudemans, 1902)}

Material: 669:19 Korppoo Åvensor, in Sedum on rock, 30.7.1966, P.T. Lehtinen, 3 exx. - 6903:422 Muurame, in forest of Myrtillus-type (ca. 100 years old), 1991, J. Laakso, 1 ex.

This species has been recorded from Sweden by Dalenius (1950), and from Denmark by Hammer (1972).

\section{Oribatellidae}

\section{Oribatella sexdentata Berlese, 1916}

Material: 666:20 Nauvo Berghamn Boskär, in decaying aspen, 30.5.1990, P.T. Lehtinen, 1 ex. — 674:26 Pöytyä Himainen, from abandoned anthill of Formica polyctena, 9.4.1983, P.T. Lehtinen, 1 ex.

No other records from the Nordic countries have been reported. In Southern and Central Europe the species seems to be common (Bernini 1977 and Schatz 1983).

Acknowledgements. I am grateful to Seppo Koponen for his reading of the manuscript and to Alice Moore for the checking of the English text.

\section{References}

Bernini, F., 1977: Notulae Oribatologicae XVII. Nuovi dati sul genere Oribatella in Italia (Acarida, Oribatei). - Redia 60: 457-505.

Dalenius, P., 1950: The oribatid fauna of South Sweden with remarks concerning its ecology and zoogeography. - Kungl. Fysiograf. Sällsk. Lund Förhandl. 20: 30 48.
- 1960: Studies on the Oribatei (Acari) of the Torneträsk territory in Swedish Lapland. I. A list of the habitats, and the composition of their oribatid fauna. - Oikos 11: 80-99.

Forsslund, K. - H., 1942: Schwedische Oribatei (Acari). I. - Arkiv Zool. 34 (10): 1-11.

Gil, J. \& Subías L. S., 1990: Oribátidos del cabo de San Vicente (Portugal) (Acari, Oribatida). - Bol. Asoc. Esp. Entomol. 14: 137-151.

Gjelstrup, P., 1978: Oversigt over Danmarks pansermider (Acarina, Oribatei). - Entomol. Meddel. 46: 109-121.

Haarløv, N., 1957: Microarthropods from Danish soils. Spolia Zool. Mus. Hauniensis 17: 1-60.

Hallas, T. E., 1978: Check list of Danish mites (Acari). Entomol. Meddel. 46: 27-45.

Hammer, M., 1972: Microhabitats of oribatid mites on a Danish woodland floor. - Pedobiologia 12: 412-423.

Hippa, H., Koponen S., Mannila R., Niemi R. \& Uusitalo M. 1988: Invertebrates of Scandinavian caves VII. Acari. - Notulae Entomol. 68: 141-146.

Karppinen, E., 1958a: Über die Oribatiden (Acar.) der finnischen Waldböden. - Ann. Zool. Soc. Vanamo 19 (1): $1-43$

- 1958b: Über die Oribatidenfauna (Acar.) in den Uferzonen von einem Teiche im Kirchspiel Lammi in Südfinnland. - Arch. Soc. Vanamo 12 (2/1957): 128143.

- 1958c: Untersuchungen über die Oribatiden (Acar.) der Waldböden von Hylocomium-Myrtillus-Typ in Nordfinnland. - Ann. Entomol. Fennici 24: 149-168.

- 1962: Zur Kenntnis der Oribatidenfauna Nordfinnlands. - Arch. Soc. Vanamo 16 (1): 36-48.

Karppinen, E. \& Krivolutsky D. A., 1982: List of oribatid mites (Acarina, Oribatei) of northern palaearctic region. I. Europe. - Acta Entomol. Fennica 41: 1-18.

Krogerus, R., 1960: Ökologische Studien über nordische Moorarthropoden. - Soc. Scient. Fenn. Comment. Biol. 21 (3): 1-238.

Lundqvist, L., 1987: Bibliografi och checklist över Sveriges oribatider (Acari: Oribatei) - Entomol. Tidskr. 108: 3-12.

Løken, A., 1966: Insekter og arachnoider samlet under det 13. Nordiske Entomologmøtets ekskursjon til Flåm (SFi: Aurland) 13.-16. august 1965. - Norsk Entomol. Tidsskr. 13: 317-386.

Mahunka, S., 1968: Some data to the mite fauna of Finland (Acari). - Ann. Hist. - Nat. Mus. Natl. Hung. 60: 261-263.

Marshall, V. G., Reeves, R. M. \& Norton, R. A., 1987: Catalogue of the Oribatida of continental U. S. A. and Canada. - Mem. Entomol. Soc. Canada 139. 418 pp.

Mehi, R., 1979: Checklist of Norwegian ticks and mites (Acari). - Fauna Norvegica (B) 26: 31-45.

Niemi, R., 1988: Oribatid mites (Acarina, Oribatei) new to the Finnish fauna. - Notulae Entomol. 68: 111-113.

Nordberg, S., 1936: Biologisch-ökologische Untersuchungen über die Vogelnidicolen. - Acta Zool. Fennica 21: 1-168. 
Nordenskiöld, E., 1901: Zur Kenntnis der Oribatidenfauna Finnlands. - Acta Soc. Fauna Flora Fennica 21 (2): 1-35.

Pérez-Iñigo, C., 1988: Catalogo de oribátidos (Acari, Oribatei) de la Sierra de Guadarrama. — Graellsia 44: 31-64.

Schatz, H., 1983: Catalogus Faunae Australiae. IXi: U. Ordn.: Oribatei, Hombilben. - Verlag der Österreichischen Akademie der Wissenschaften, Wien. 118 pp.

Sellnick, M. \& Forsslund K.-H., 1955: Die Camisiidae Schwedens (Acar. Oribat.). - Arkiv Zool. 8: 473-530.

Solhøy, T., 1975: Dynamics of Oribatei populations on Hardangervidda. - In: Wielgolaski, F. E. (ed.), Fennoscandian Tundra Ecosystems. Part 2. Ecological Studies 17: 1-337.

Strand, E., 1910: Neue Beiträge zur Arthropoden-Fauna Norwegens nebst gelegentlichen Bemerkungen über deutsche Arten. I. V. — Nyt Mag. Naturvid. 48: 307352.

Subias, L. -- S., 1977: Taxonomia y Ecologia de los Oribatidos Saxicolas y Arboricolas de la Sierra del Guadarrama (Acarida, Oribatida). - Catedra de Artropodos, Univ. Complutenese de Madrid, 24: viii + 379 pp.

Subías, L. S. \& Balogh, P. 1989: Identification keys to the genera of Oppiidae Grandjean, 1951 (Acari: Oribatei). - Acta Zool. Hung. 35: 355-412.

Thamdrup, H. M., 1932: Faunistische und ökologische Studien über dänische Oribatiden. - Zool. Jahrb. 62: 289-330.

Uusitalo, M., 1993: The identification of mites (Acari) from birds' nests by Nordberg (1936) - revaluation. - EURAAC Newsletter 6: 5-9. 